Palchuk O.V., cand.sc.(econ.), assoc. prof., associate professor at the department of auditing, accounting and taxation, Central Ukrainian National Technical University, Gai O.M., cand.sc.(econ.), assoc. prof., associate professor at the department of auditing, accounting and taxation, Central Ukrainian National Technical University

\title{
ACCOUNTING POLICY AND ITS ROLE IN THE FORMATION OF INFORMATION SUPPORT OF INNOVATION ACTIVITY MANAGEMENT
} \author{
доцент кафедри аудиту, обліку та оподаткування, \\ доцент кафедри аудиту, обліку та оподаткування, \\ Центральноукраїнський національний технічний університет

\section{ОБЛІКОВА ПОЛІТИКА ТА ІІІ РОЛЬ У ФОРМУВАННІ ІНФОРМАЦІЙНОГО ЗАБЕЗПЕЧЕННЯ УПРАВЛІННЯ ІННОВАЦІЙНОЮ ДІЯЛЬНІСТЮ}

Пальчук О.В., канд. екон. наук, доцент, Гай О.М., канд. екон. наук, доцент,

Formulation of the problem. Accounting and preparation of financial statements in Ukraine are carrying out based on the national level regulations. This allows forming accounting support and preparing financial statements according to unified principles and forms and ensures the comparability of accounting information. However, this does not mean that companies cannot choose the most appropriate and optimal forms and options for accounting. Therefore, an important component of accounting and economic work at the enterprise is the justification of accounting policy, which should ensure the effective functioning of the entire accounting system. Accounting options that determined by the accounting policy are formed, first of all, under the influence of two circumstances, namely: the current legislation, which provides alternatives to certain methods and methods of accounting, as well as the existence of various options for business activities determined by industry, organizational, technological features of business entities. Innovation activity is very specific, complex, and multidirectional, which presupposes the existence of multimodal activity and the variety of its accounting and information support. In these conditions, it is especially important to study the problematic aspects of building an accounting system and the formation of accounting policies, taking into account the characteristics and specifics of innovation activity.

Analysis of recent research and publications. Recently, the topic of innovation activity is quite widely represented in the economic literature. It is worth noting the study of the essence of innovation and its features in the works V. Lysak [1], T. Polozova, D. Kravtsun [2]. Such scientists as V. Zhuk [3], Ya. Krupka, S. Pytel, I. Melnychuk [4], studied problems of accounting support of innovation activity. Construction of the accounting system of innovation activity taking into account branch specificity was investigated by O. Chereshniuk (sugar industry) [5], I. Melnychuk (textile industry) [6], N. Stoliarchuk (scientific field) [7]. Some aspects of the accounting policy of innovation activity are disclosed in the works of V. Yasyshena, who analyzes the accounting policy of intangible assets [8], T. Yefimenko, who examines the valuation of assets of innovative origin [9], H. Davydov, who revealed the issues accounting policy in terms of innovation costs [10].

Without diminishing the importance of these studies, we note that many problems of information support of innovation activity remain unresolved. For example, there is no clear idea of innovation as a specific object of accounting. Insufficient attention is also paid to the systematic study of accounting support of innovation activity and the systematic study of accounting policy as a tool for managing the process of formation of information resources of innovation activity. 
Setting objectives. The aim is to study the features of innovation activity and its accounting. Also in the article, the influence of these features on the formation of accounting policy for the purpose of construction of effective accounting and information system of management of innovation activity of the enterprise is defined.

Presentation of the main research material. Innovation activity has features that significantly affect the construction of the accounting system. These features should be taken into account in the formation of accounting policy. Therefore, the process of formation of accounting and information support for innovation management should begin with a study of the specifics and features of the innovation sphere. This allows us to determine the features of accounting and information support, and also identify and systematize the objects of innovation activity and formulate accounting tasks for certain objects of innovation activity.

Solving these problems is the basis for the formation of the accounting policy. Interpretation of accounting policy as a tool for accounting management [10] allows us to say that accounting policy in terms of innovation activity at the enterprise level should include the following components:

- methodological issues (choice of methods of assets valuation of innovative origin, methods of accounting and allocation of costs related to innovation activities, methods of internal accounting);

- organization of the technology of accounting process at the stages of observation, measurement, registration and systematization, generalization and transmission of information about innovation activity;

- organization of the accounting and economic service of the enterprise for the formation of information resources of innovation activity.

The formation of accounting policies to create an information resource for innovation activity management should include the following steps:

- determination of objects of accounting and accounting nomenclatures related to innovation activity;

- classification of costs and revenues related to innovation activity; determination of the sphere of responsibility and places of origin of expenses, separation of the centers of expenses and incomes of innovation activity;

- selection of analytical tools taking into account the identified objects of innovation activity and the peculiarities of innovation processes of a particular enterprise;

-implementation of methodological aspects of accounting policy (choice of methods of assets valuation of innovative origin, methods of accounting, distribution, and coverage of costs of an innovative nature);

- refinement of organizational aspects of accounting policy related to the work of accounting and economic personnel to meet the needs of innovation (determination of the organizational structure of the relevant unit, division of responsibilities, division, and cooperation of labour);

- organization of the technological component of the accounting policy in part of innovation activity (determination of the list of primary documents and refinement of the flow of documents; selection of the system of accounting registers and determination of the procedure for their maintenance; construction of a working chart of accounts).

Determining by the accounting policy of methodological, technical, and organizational aspects of accounting for objects of innovation activity provides the development of accounting models for the reflection of innovation processes. At the same time, algorithms for the formation of indicators of financial and statistical reporting and their use in the management of the innovation sphere, as well as the choice of methods of internal accounting for the purposes of innovation activity management are determined.

Peculiarities of the system of accounting reflection of innovation activity, which should be taken into account when forming the accounting policy of the enterprise, are determined, primarily, by the peculiarities of the innovation activity itself. Let us analyze the features of innovation activity and their impact on the accounting system.

Innovation activity is an extremely difficult and integrated concept. It includes different in content and form of business transactions that reflect the different options for financing innovation activity:

- these are own or borrowed funds, funds from the state budget, or funds from specialized state and municipal innovative financial and credit institutions;

-the organization of the innovation process can be carried out by own forces or third-party organizations;

- which objects are related to innovation (products, fixed assets, intangible assets, and organizational, technological, management decisions);

- what are the areas of commercialization of the innovative product (use in its own production or sale, transfer under a lease agreement or license agreement);

- what is the method of covering the costs associated with the innovation activity (capitalization or attribution to the costs of the period, provisioning, or deferred costs).

This causes a special complexity of accounting for innovation activity.

The multidirectional innovation activity, the diversity of goals, and objectives of innovation development form a wide range of innovative projects, programs, and business operations, which 
necessitates classification. Construction of accounting and information support for innovation activity management should be carried out in three areas: financing of innovation, creation (acquisition) of an innovative product and commercialization of innovation results. These directions differ significantly in the content and organization of activities, the type of resources required for their implementation, the level of costs, the method of their repayment. As a result, the objects and business operations that require accounting, as well as options for their evaluation and accounting methods will be different.

The innovative direction of the enterprise activity is extremely multifaceted. Innovation activity management requires a large amount of information resources, which are provided, primarily, by the accounting system. A prerequisite for the implementation of the needs of innovation activity management is the separation of information resources about the objects of innovation in the accounting system. The current accounting system does not provide separate synthetic accounts for the accounting of innovation costs, products, revenues, and results from innovations. In our opinion, this is justified, because innovation activity is an extremely multifaceted concept. Innovation activity is inherent in all areas and kinds of activities; it is multi-stage and does not always have clear boundaries. The activity of the enterprise according to National Ukrainian Accounting standards is divided into operational, financial, investment. In the same way, the information is disclosed in accounts of expenses and incomes. Innovation activity is related to financial activity at the stage of raising equity or debt capital for innovation; with investment activity in the implementation of investment projects to upgrade the equipment; with other operational activities in the process of applied research; with the main operating activity at the stage of serial production of innovation products.

Therefore, we do not consider appropriate recommendations for the separation of individual synthetic accounts for the accounting of objects of innovation, especially if they are accounts of the eighth class, which are designed to account for costs by elements [11]. We share the point of view of I. Melnychuk, who believes that "Expansion of the information field of second-order accounts and the introduction of new analytical positions on third-order accounts... will provide more complete and reliable information about innovation processes in the enterprise to evaluate the effectiveness of innovation projects and programs" [6].

Thus, in order to form information resources of innovation activity, it is necessary to separate objects of innovation activity in the system of accounts. In this case, the identification of objects of innovation should be carried out by introducing additional accounts of the second-order and third-order.

Within the framework of accounting policy in the development of analytical tools, it is necessary to take into account the objects of innovation activity and the peculiarities of innovation processes of a particular enterprise. For a periodic generalization of information about innovation activities, it is advisable to provide for the accounting policy of the enterprise to use the cumulative registers of innovation costs, revenues, sources of funding, which are reflected in various accounts.

An essential feature of innovation activity is that it requires significant financial resources that can pay off only in the future. Today, companies often do not have enough funds to finance innovation projects. Innovation activity to renew non-current assets is often financed by bank lending. Creating innovative products has a long payback period and increased risk. Therefore, it is advisable to finance such projects at the expense of venture funds based on equity participation or long-term lending. Recently, the importance of new forms of innovation financing without financial intermediaries such as crowdfunding is growing [12]. There are different options for accounting for the process of financing innovation, depending on the affiliation of financial resources, terms and conditions of their provision, the presence of financial and non-financial interests of investors. Figure 1 shows the objects and business transactions that require accounting for different sources and conditions of financing innovation.

Within the framework of the accounting policy, taking into account the peculiarities of the activity of a particular enterprise, it is necessary to perfect the methodological, technological, organizational aspects of the selected accounting objects. At the same time, it is especially important to strengthen the analytical properties of financial accounting in order to ensure separate accounting of innovative financing on separate sub-accounts of accounts of sources of financing and organization of settlements with participants in financing with investor participation in the capital. Since accounting for different sources of funding is conducted on different accounts $(40,44,46,48,50$, and 60) - this creates inconvenience in the use of such information in the management of innovation, we consider it appropriate within the technological aspects of accounting policy to provide a cumulative register of sources financing of innovation activities according to the above classification.

A characteristic feature of innovation is the presence of elements of uncertainty in achieving the planned results, which causes risks. Therefore, an important task of effective innovation activity is risk management, and this requires appropriate accounting support. An economic entity's risk is understood as the probability of losses that occur when making management decisions in conditions of information asymmetry and uncertainty. Economic risk reflects the degree of deviation from the goals, the degree of damage. Therefore, to manage the economic risks of innovation activity, accounting must provide separate accounting and continuous monitoring of costs, revenues, and financial results of innovation. 


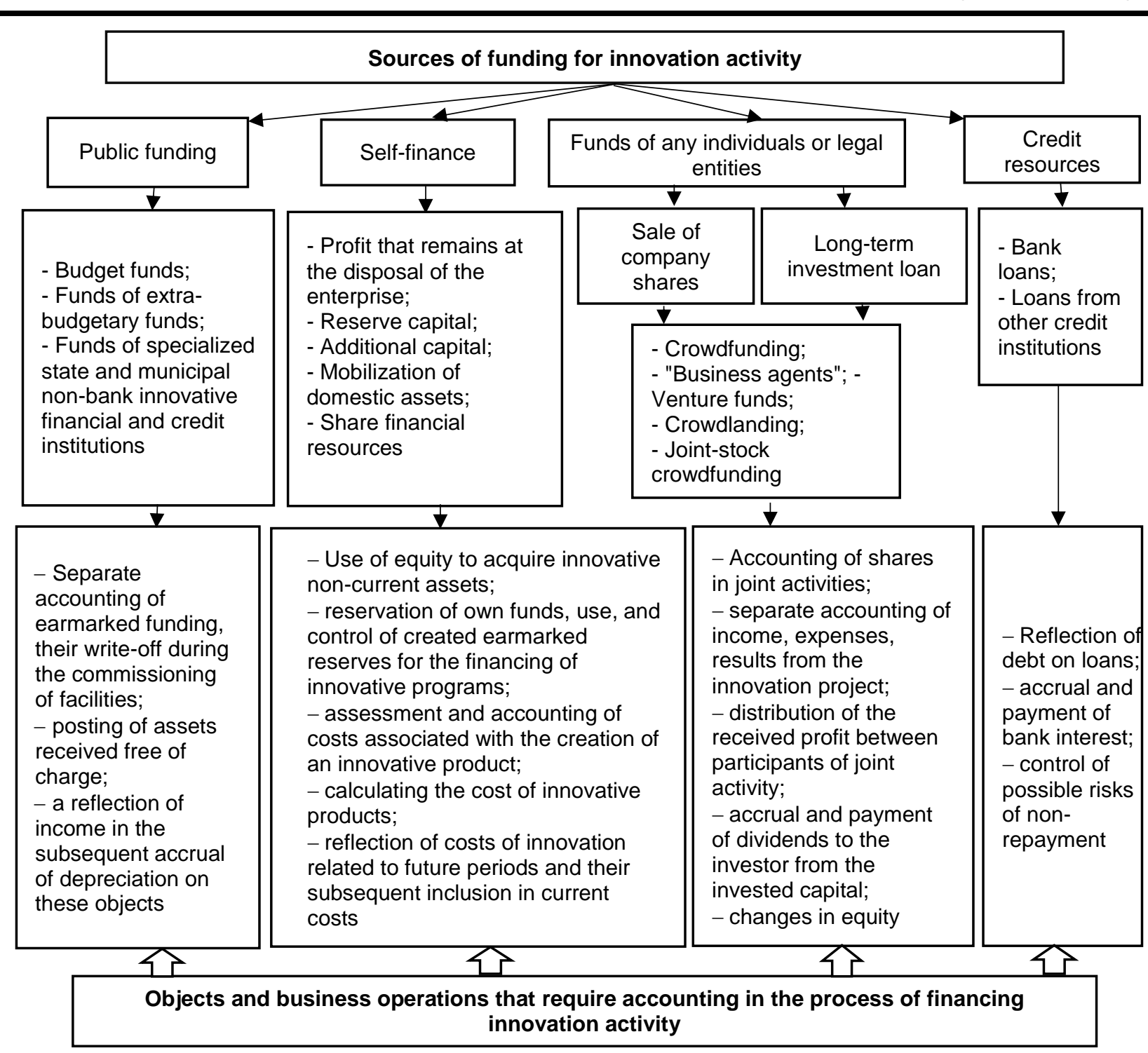

Fig. 1. Accounting facilities by sources of funding for innovation

Source: Compiled by the authors based on [13].

One of the main accounting objects in the information support system of innovation activity management is costs. The statement of B. Valuev and O. Kantaeva is fair that: "The only indicator that allows you to bring together and determine the total amount of innovation activity, can only be costs - for the project, product, process, group of processes, their total value" [13]. Innovation costs are not always related to the corresponding revenues. The costs of innovation and the effect of its implementation often do not coincide in time. Significant costs are often caused by research and search, which do not end with the development of an innovation product. Costs arise at all stages and processes of innovation without exception. This object is especially difficult to account for at the stage of creating (purchasing) an innovation product. As can be seen from the information shown in Figure 2, the accounting of these processes is carried out for two objects - costs and assets of an innovative nature, to assess which also requires information about costs.

The accounting policy of the enterprise in terms of costs of innovation activity at this stage should take into account the nature of this activity to create or purchase an innovation product; the nature of the created innovation product; cost and a payback period of the innovation project; cost recovery way; sphere and type of activity. It should determine the methodological aspects of cost accounting related to:

- capitalization of costs for the creation of an innovation product, provided that there is a connection between these costs and income in future periods;

- methods of accumulation and write-off of costs for the implementation of innovation projects related to the main activity;

- expenditure - methods of allocation and write-off of innovation costs, which are reflected in the costs of future periods;

- methods of formation and use of appropriated reserves for financing innovation projects; 
- definition of objects of accounting of costs of innovation activity and objects of calculation of the prime cost of an innovation product; activity;

- defining of the sphere of responsibility, places, and centers of occurrence of expenses of innovation

- methods of distribution of indirect costs when calculating the cost of innovation products.

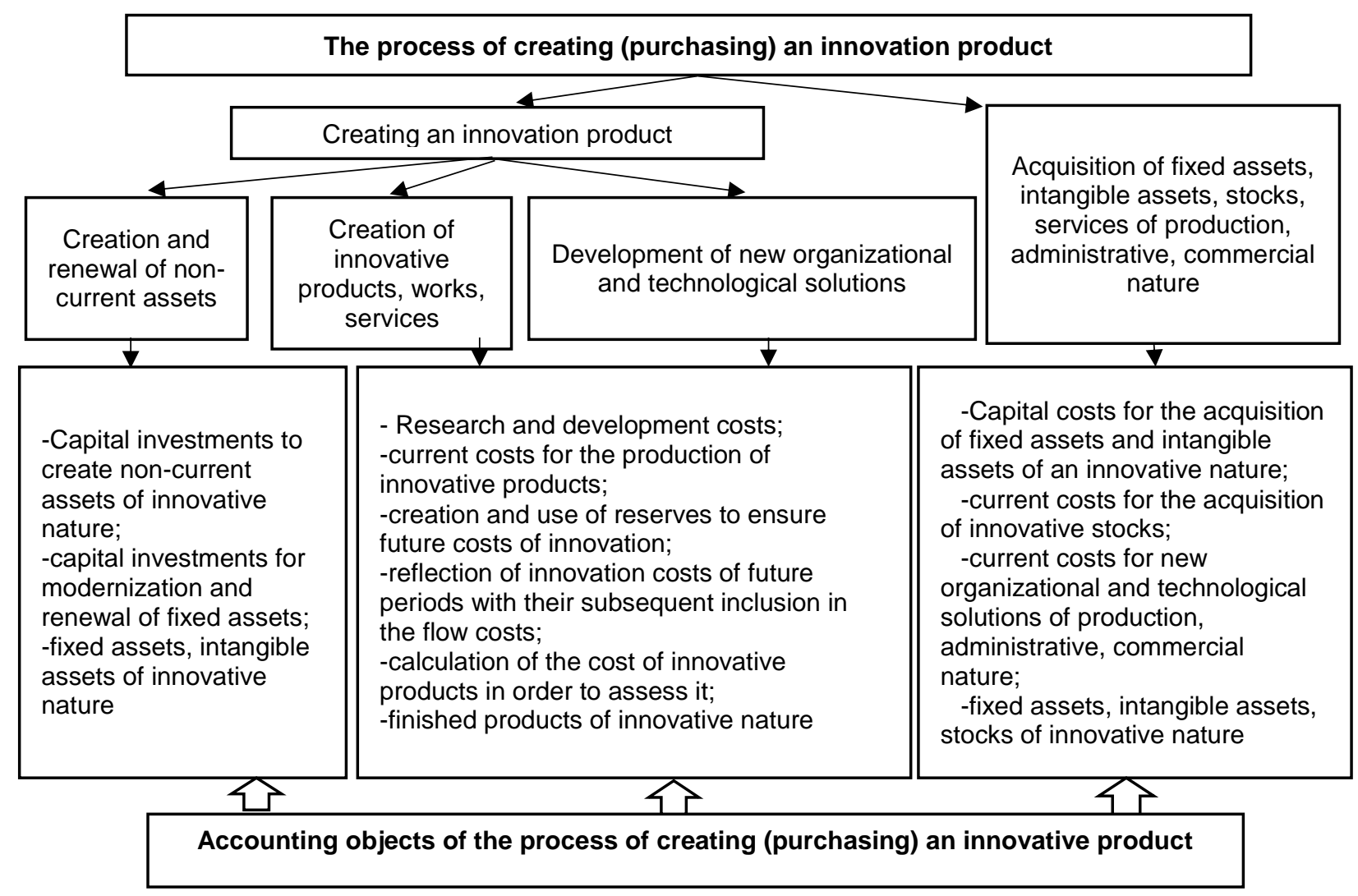

Fig. 2. Accounting objects in the areas of the process of creating (purchasing) an innovative product

Source: Compiled by the authors based on [5].

When developing an accounting policy at this stage, the development of analytical tools for the formation of information support for the management of innovation costs within management accounting becomes especially important.

Recently, the relevance of the process of commercialization of innovation results has been increasing. Figure 3 summarizes the main objects of financial accounting in the areas of use of innovative products in the process of their commercialization, in particular: for the needs of own production, for sale, lease, and transfer of the right to use innovative objects under license agreements.

Within the accounting policy, it is necessary to provide tools for separate accounting of costs, revenues, and financial results for individual projects, products, processes at the stage of commercialization. These should include objects of accounting for costs, revenues, and financial results; analytical tools for their reflection in the accounts, accounting records, and internal reporting for the accumulation and generalization of information on costs and revenues of innovative programs and projects in the context of the proposed classification.

At the same time, the algorithm of commercial use of innovations involves conducting various studies at different stages of their development and implementation.

For such research and procedures, it is often necessary to evaluate objects at fair value, involve independent auditors and experts, assess the value of innovative objects in an active market, and take into account information about buyers, creditors, customers, investors. Such information is not always available in system accounting but is extremely important for making informed management decisions.

In this regard, we consider it appropriate to recommend the need to isolate a separate group of objects in the information resources of innovation, which are outside the accounting system [8]. Such nonsystem objects of accounting may include:

- qualification level of employees engaged in research and innovation;

- results of the evaluation of innovative assets by experts, independent auditors, appraisers; 
- databases on the market of innovative objects, the market of potential consumers of an innovative product, customer databases;

-the results of the technological audit regarding the assessment of the qualitative characteristics of the innovative product and the determination of the legality of the acquisition of security documents for the innovative product;

-the results of the economic audit to determine the feasibility of investment and payback of the project;

- calculations of economic efficiency of an innovative product;

-the results of marketing research on the advantages and disadvantages of an innovative product, analysis of the potential market for the possibility of its commercial use;

- development of business projects to promote an innovative product;

- assessment of the effect of innovation activities of social and environmental nature.

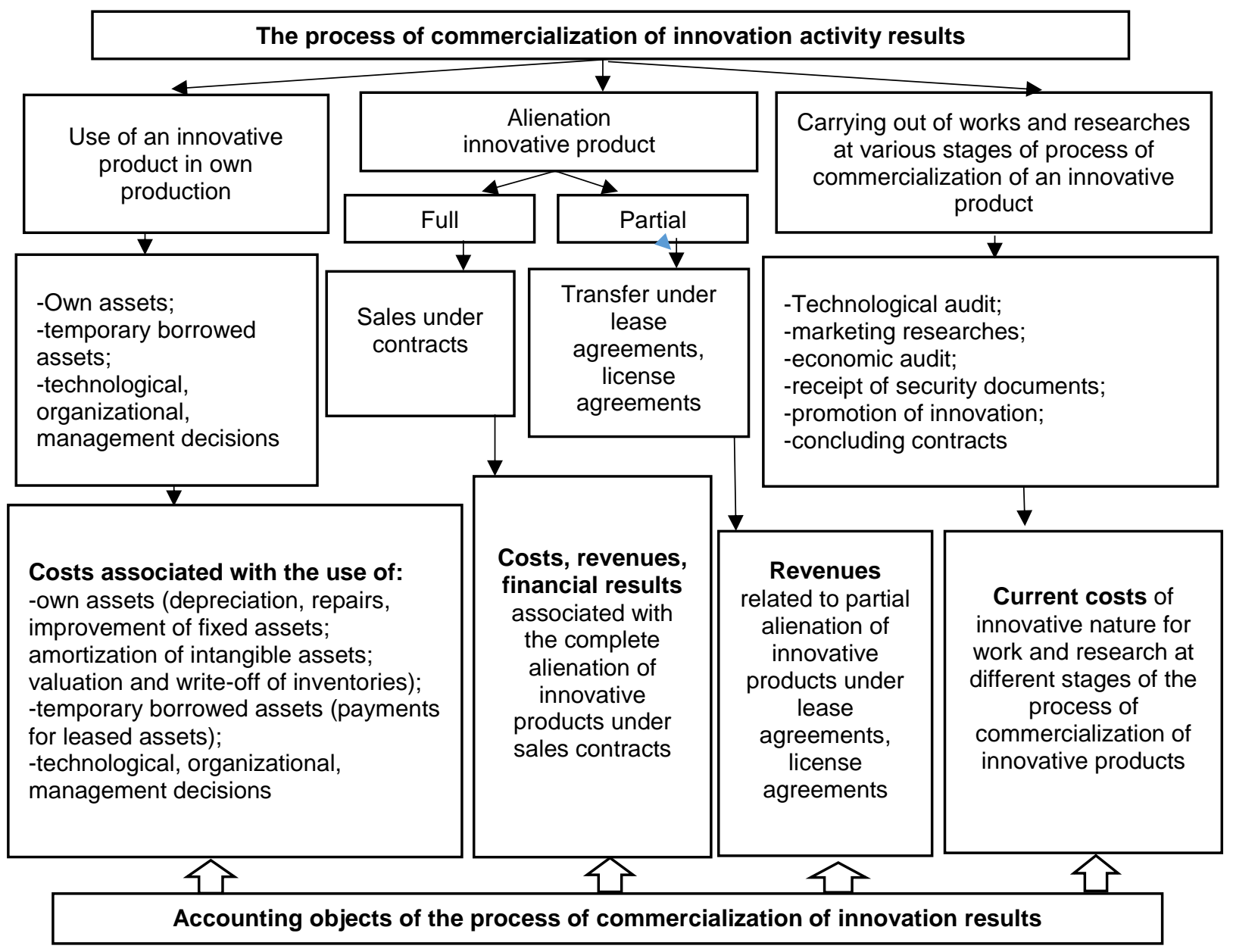

Fig. 3. Accounting objects in the areas of commercialization of the results of innovation Source: Compiled by the authors

Not all of these objects can be measured by cost indicators, which are reflected in the system of accounting. Therefore, within the accounting policy in the formation of information resources for innovation activity management, it is advisable to provide accounting registers for the current accumulation and generalization of information in certain areas of non-system objects of accounting. It is also desirable to be able to accumulate non-financial information on non-system objects of accounting for innovation in internal (management) reporting. Cards and journals of innovation proposals can be used as additional registers of management accounting. Similar documents may be questionnaires and journals of registration of the results of expert assessments regarding the organization, the presence of bottlenecks in the production process; logs of daily accounting of applications for current repairs of technological equipment, etc.

When developing an accounting policy, it is advisable to use the capabilities of integrated reporting to accumulate and summarize non-financial information of an innovative nature. Integrated reporting allows you to display advanced information about innovation activities required by different users. It uses a variety of information about changes in financial and non-financial indicators because of innovation, visually and in an accessible form reflects the results of innovation, its impact on the internal and external environment of the 
enterprise, the efficiency of innovation processes, cost structure. In addition, these reports form conclusions about the effectiveness of the innovation management system.

However, only based on surveys of continuous accounting can draw the right conclusions and make adequate decisions. Therefore, the system of information support for innovation activity management should be based on the principles of systematization with maximum use of tools and methods of financial accounting. When refinement such elements of the method of financial accounting as accounts, reporting, special attention should be paid to the development of analytical tools in order to maximize the fulfillment of the requirements of management accounting and the needs of internal reporting to manage innovation activity.

Research of features of innovation activity allows forming requirements to the system of its accounting display that should be considered at the formation of accounting policy of the enterprise for the purpose of construction of an effective system of accounting and information support of the innovation activity management:

- building a system of information support for innovation activity management requires a clear identification of the objects of this activity and the objects of its accounting, and given the special complexity and diversity of innovation processes is especially important classification and systematization of objects of innovation;

- the implementation of management functions requires the separation of information about the objects of innovation (costs, revenues, financial results, and assets of innovative nature);

- to identify the objects of accounting for innovation, it is advisable to supplement such synthetic accounts as $23,26,39,70,79,90,94,44,47,48$ by sub-accounts of the second order, which will accumulate information about the innovation activity, as well as analytical accounts of the third the order that will concretize the innovation process of the enterprise;

- information support for innovation activity management should be based on the principles of systematization with maximum use of tools and methods of financial accounting;

- the increasing of the analytical nature of financial accounting becomes especially important in order to maximize the requirements of management accounting and the formation of internal reporting for the needs of innovation management;

- the importance of non-financial indicators determines the need to display and accumulate information about non-systemic objects of accounting (level of qualification of employees, databases, expert opinions, marketing research, technological and economic audit).

Conclusions from the study. It is established that the special complexity and multidirectional of innovation activity, which is the reason for the existence of multivariate of the activities itself and its accounting and information support, determine the special relevance of accounting policy in the formation of information support for innovation management. The main stages of the procedure of formation of accounting and information support of innovation activity management are proposed and the role of accounting policy, in this case, is clarified. The content, stages, and features of the formation of accounting policy in order to create an information resource of innovation activity are described. Based on the analysis of the features of innovation, the requirements for the accounting system are formed, which should be taken into account when forming the accounting policy of the enterprise to build an effective system of accounting and information support for innovation activity management.

Defining the features of accounting and accounting policy of innovation activity allows streamlining the methodology of accounting and improving the transparency of reporting, to form models of accounting reflection of various processes of innovation and sources of funding in the accounts. Further research can be carried out in the direction of practicing a specific method of accounting, elements of accounting policy and accounting models, taking into account industry specifics, the specifics of the business, and innovation of specific enterprises.

\section{Literature}

1. Лисак В. Ю. Аналіз сутності інноваційних процесів та організації інноваційної діяльності підприємств. Науковий вісник Міжнародного гуманітарного університету. 2016. Вип. 19. С. 66-69. URL: http://nbuv.gov.ua/UJRN/Nvmgu_eim_2016_19_15 (дата звернення: 21.01.2021).

2. Полозова Т. В., Кривцун Д. Ю. Інноваційна діяльність підприємства та економічна сутність інноваційного процесу. Науковий вісник Міжнародного гуманітарного університету. Серія :

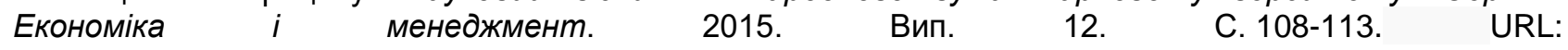
http://nbuv.gov.ua/UJRN/Nvmgu_eim_2015_12_27 (дата звернення: 21.01.2021).

3. Жук В. М. Концептуальні підходи вирішення поверхневих та глибинних проблем обліку інноваційної діяльності. Облік $i$ фонанси АПК. 2011. № 1. C. 36-39. URL: http://magazine.faaf.org.ua/konceptualni-pidhodi-virishennya-poverhnevih-ta-glibinnih-problem-oblikuinnovaciynoi-diyalnosti-1214.html (дата звернення: 22.01.2021).

4. Крупка Я.Д., Питель С.В., Мельничук І. В. Облік, оподаткування і правове регулювання інвестиційно-інноваційної діяльності : навч. посіб. 3-тє вид., переробл. і доповн. Тернопіль : Крок, 2017. 264 c. 
5. Черешнюк О. М. Облік та аналіз інноваційної діяльності на прикладі цукрової промисловості : авторефр. дис. на здобуття наук. ступеня канд. екон. наук : 08.00.09. Тернопіль, 2015.20 с. URL: http://dspace.wunu.edu.ua/handle/316497/754 (дата звернення: 23.01.2021).

6. Мельничук І.В. Облік і аналіз інновацій у сфері випуску та збуту продукції текстильної промисловості : автореф. дис. на здобуття наук. ступеня канд. екон. наук : 08.00.09. Тернопіль, 2011. 21 c. URL: http://dspace.wunu.edu.ua/jspui/handle/316497/1557 (дата звернення: 23.01.2021).

7. Столярчук Н. М. Об'єкти обліку і внутрішнього аудиту інноваційної діяльності. Економіка АПК. 2018. № 7. C. 55-63. URL: http://nbuv.gov.ua/UJRN/E_apk_2018_7_8 (дата звернення: 25.01.2021).

8. Ясишена В. В. Принципи облікової політики нематеріальних активів. Інноваційна економіка. 2019. № 3-4. C. 156-162.

9. Єфріменко Т.І. Активи інноваційного походження: вдосконалення облікової політики підприємства. Інноваційна економіка. 2014. № 2. С. 167-172. URL: http://nbuv.gov.ua/UJRN/inek_2014_2_27 (дата звернення: 25.01.2021).

10. Облікова політика : навч. посіб. / Давидов Г. М. та ін. ; за заг. ред. Г. М. Давидова. 2-ге вид., перероб. і доп. Кропивницький : ПП «Ексклюзив-Систем», 2017. 362 C. URL: http://dspace.kntu.kr.ua/jspui/handle/123456789/7357 (дата звернення: 25.01.2021).

11. Гришко Н. В., Скубак Ю. А. Бухгалтерська модель обліку інноваційних витрат промислових підприємств. Сталий розвиток економіки. 2013. № 1. С. 242-248.

12. Кучеренко Т. Є., Ратушна О. П., Мельник Л. Ю. Облік фінансування інноваційної діяльності підприємства. Облік і фрінанси. 2019. № 1(83). С. 35-43. URL: http://nbuv.gov.ua/UJRN/Oif_apk_2019_1_7 (дата звернення: 25.01.2021).

13. Валуєв Б., Кантаєва О. Деякі питання обліку інноваційних витрат і джерел їх покриття: концептуальний аспект. Бухгалтерський облік і аудит. 2009. № 12. С. 28-35.

\section{References}

1. Lysak, V.Yu. (2016), "Analysis of the essence of innovation processes and organization of innovation activities of enterprises", Naukovyi visnyk Mizhnarodnoho humanitarnoho universytetu, Iss. 19, pp. 66-69, available at: http://nbuv.gov.ua/UJRN/Nvmgu_eim_2016_19_15 (access date January 21, 2021).

2. Polozova, T.V. and Kryvtsun, D.Yu. (2015), "Innovative activity of the enterprise and economic essence of innovation process", Naukovyi visnyk Mizhnarodnoho humanitarnoho universytetu. Seriia : Ekonomika $i$ menedzhment, Iss. 12, pp. 108-113, available at: http://nbuv.gov.ua/UJRN/Nvmgu_eim_2015_12_27 (access date January 21, 2021).

3. Zhuk, V.M. (2011), "Conceptual approaches to solving superficial and deep problems of accounting for innovation", Oblik i finansy APK, no. 1, pp. 36-39, available at: http://magazine.faaf.org.ua/konceptualnipidhodi-virishennya-poverhnevih-ta-glibinnih-problem-obliku-innovaciynoi-diyalnosti-1214.html (access date January 22, 2021).

4. Krupka, Ya.D., Pytel, S.V. and Melnychuk I.V. (2017), Oblik, opodatkuvannia i pravove rehuliuvannia investytsiino-innovatsiinoi diialnosti [Accounting, taxation and legal regulation of investment and innovation activities], tutorial, 3rd ed., revised and supplemented, Krok, Ternopil, Ukraine, 264 p.

5. Chereshniuk, O.M. (2015), "Accounting and analysis of innovation on the example of the sugar industry", Thesis abstract of Cand.Sc.(Econ.), Ternopil, available at: http://dspace.wunu.edu.ua/handle/316497/754 (access date January 23, 2021).

6. Melnychuk I.V. (2011), "Accounting and analysis of innovations in the field of production and marketing of textile industry", Thesis abstract of Cand.Sc.(Econ.), Ternopil, available at: http://dspace.wunu.edu.ua/jspui/handle/316497/1557 (access date January 23, 2021).

7. Stoliarchuk, N.M. (2018), "Objects of accounting and internal audit of innovation", Ekonomika APK, no. 7, pp. 55-63, available at: http://nbuv.gov.ua/UJRN/E_apk_2018_7_8. (access date January 25, 2021).

8. Yasyshena, V.V. (2019), "Principles of accounting policy for intangible assets", Innovatsiina ekonomika, no. 3-4, pp. 156-162.

9. Yefimenko, T.I. (2014), "Assets of innovative origin: improving the accounting policy of the enterprise", Innovatsiina ekonomika, no. 2, pp. 167-172, available at: http://nbuv.gov.ua/UJRN/inek_2014_2_27 (access date January 25, 2021).

10. Davydov, H.M. (ed.) (2017), Oblikova polityka [Accounting policy], 2nd ed., revised and supplemented, PP "Ekskliuzyv-System", Kropyvnytskyi, Ukraine, 362 p., available at: http://dspace.kntu.kr.ua/jspui/handle/123456789/7357 (access date January 25, 2021).

11. Hryshko, N.V. and Skubak, Yu.A. (2013), "Accounting model of accounting for innovation costs of industrial enterprises", Stalyi rozvytok ekonomiky, no. 1, pp. 242-248,

12. Kucherenko, T.Ye., Ratushna, O.P. and Melnyk, L.Yu. (2019), "Accounting for financing the innovative activities of the enterprise", Oblik $i$ finansy, Vol. 1 (83), pp. 35-43, available at: http://nbuv.gov.ua/UJRN/Oif_apk_2019_1_7. (access date January 25, 2021).

13. Valuiev, B. and Kantaieva, O. (2009), "Some issues of accounting for innovation costs and sources of their coverage: a conceptual aspect”, Bukhhalterskyi oblik i audit, no. 12, pp. 28-35. 